\title{
Firm’s Asset Structure Change: Evidence From Industrial, Commercial Machinery and Computer Equipment in the U.S. Market*
}

\author{
Gang Chen \\ Shandong University of Technology, Zibo, China \\ Mahfuzul Haque \\ Indiana State University, Terre Haute, USA
}

\begin{abstract}
Asset structure is an important and explicit indicator of asset investment and financial performance of a firm. As previous studies on asset structure did not reveal the actual tendency of specific manufacturing industry, this research examines the asset structure of the chosen manufacturing industry. Using panel data of the sample companies and generalized moment method (GMM) for the empirical testing, the results of the empirical analysis indicate that the average of the asset structure (represented by the ratio of current asset to total asset) almost holds on firmly to a constant value of 0.6, through the period of 2006 to 2013. No evidence reveals the collective characteristic of volatility during this period. In addition, the observed data present a slight-downward curve in the level of average current asset ratio during this period. Asset structure, together with first difference of return on asset (ROA) and return on equity (ROE), is the significant determinant of ROA. These findings may have a profound influence on directing internal investment and some sample companies may be taken as an example by corporate financial policy maker from both developed and developing countries.
\end{abstract}

Keywords: asset structure, financial ratios, financial performance, return on asset (ROA), return on equity (ROE)

\section{Introduction}

A firm operates utilizing its assets and capital. Generally, assets have been decided, established, or purchased, since the firm started and the assets soon became firm specific, because their size and type demonstrate the characteristic and the management of the industry in which the firm is engaged in. The above

\footnotetext{
* Project Supported: This work was supported by International Cooperation Training Program, Shandong Education Department and Research Fund for the Doctoral Program, Shandong University of Technology. Gang Chen wishes to express sincere thanks and tremendous respect to Dean of SCOB Dr. Brien Smith and Chair of AFIRM, SCOB Dr. Steven Lamb for providing him the opportunity to be a visiting scholar at SCOB, ISU during 2013 to 2014. He also wishes to express his gratitude and special thanks to Dr. Mahfuzul Haque for the guidance, encouragement, and joint efforts in carrying out the research. But any error or omission is the sole responsibility of the authors. The original data applied in this paper is intended to send to any reader upon request.

Gang Chen, Ph.D., associate professor, Department of Financial Management, Business School, Shandong University of Technology, Zibo, 255012 Shandong, P. R. China.

Mahfuzul Haque, Ph.D., professor of Finance, Department of AFIRM, Scott College of Business, Indiana State University, Terre Haute, IN 47809, USA.

Correspondence concerning this article should be addressed to Gang Chen, Business School, Shandong University of Technology, Gongqingtuan West Road 88\#, Zhangdian, Zibo, 255012 Shandong, P. R. China. E-mail: sdutcg@126.com.
} 
description is based on the whole industry level. In terms of assets themselves, there is a problem of structure. The structure within the assets is formed from the desire of the management to operate effectively and produce increased return, because each asset serves in different side of the operation and functions in its own way. It follows that the structure issue is the decision of matching and proportion among the assets. Why would different parts of total asset of a firm, ordinarily grouped as current assets and long-term assets, be matched or in proportion? The reason is that a concept, which connotes a firm, is involved in a tradeoff in daily operation that it will have lower return on investment, when it invests more fund in current assets while it may get lower liquidity risk, has been existing both in academic theory and financial management practice for quite a long time. Consequently, in this sense, the management has the intrinsic motivation to reach or maintain the target asset structure.

In fact, the asset structure of a firm is at the discretion of the firm management individually. The practice may also have deviation from the theory. In addition, that fact raises another problem: Which structure is better or the best in practice and how to structure the assets will be favorable now that asset structure may markedly impact on the financial performance? Therefore, this paper attempts to investigate the asset structure feature of manufacturing industry in the United States market and gives conclusions about better practice and financial policy recommendations.

Following the introduction in section 1, the paper is organized as follows: Section 2 presents the literature review followed by section 3 , which presents the data source. Section 4 presents empirical methodology and the model. Section 5 discusses the findings and analyzes the results and finally section 6 concludes the paper.

\section{Literature Review}

On one hand, comparably, capital structure has been widely researched after the remarkable literature of Modigliani and Miller (1958), especially after "the capital structure puzzle" (Myers, 1984) aroused in 1984. As the literatures on this topic grow, it has been recognized nowadays as a profound field in finance. On the other hand, only a few literatures, which can be categorized into several following groups, discussed asset structure of a firm.

Literatures of Myers (1977), Myers and Majluf (1984), Stulz and Johnson, (1985), Sibilkov (2009), and Muritala and Ajibola (2013), which can be seen as the first group on this subject, aim to study the relationship between asset structure and capital structure from the standpoint of financial decision-making. They depict that corporate assets often impose a direct and significant impact on the financial policy. The study of Sanyal and Mann (2010) reveals that start-up firms with different physical assets level may opt to have various financial resource and structure. Akintoye (2008) also argued that a firm will have smaller costs of financial distress than that relies more on intangible assets, if it retains large investments in tangible assets. To a certain degree, they emphasize capital structure while imply asset structure.

The second group, like Czyzewski and Hicks (1992) and Jose, Lancaster, and Stevens (1996), is exemplary in explaining how ongoing cash or other asset, on the item basis, affects firm profitability, whereas Arbidane and Zelgalve (2012) mainly focused on asset management that how the average level of current asset changed over a certain period of time and were influenced by macro or micro factors. An (2013) also asserted that policy of private property protection in China has apparently increased the investment willingness in both fixed assets and intangible assets of an enterprise. All of these articles suggest the possible factors that may affect the formation of the asset structure. 
The third group examines how working capital policy affects financial performance, which is oftentimes represented by some measures, like return on asset (ROA) and return on equity (ROE) and how working capital management is able to impact financial policy. De Almeida and Eid (2014) suggested that more cash engagement than working capital investment and increasing the level of working capital at the beginning of a fiscal year can reduce company value averagely. Ding, Guariglia, and Knight (2013) explained that an active management of working capital may help firms to alleviate the effects of financing constraints on fixed investment.

The fourth group focuses on some other functions that the asset structure serves in the firm operation or in special circumstances. Ambrose and Megginson (1992) showed that an increasing fraction of fixed assets in a firm's total asset structure is significantly associated with the chance that the firm becomes an acquisition target. The empirical analysis of Constand, Osteryoung, and Nast (1991) indicates that a small firm's asset structure is the most important determinant of the use of debt financing. Still in the work of Muritala and Ajibola (2013), it is found that firms who have more tangible assets are less likely to experience financial constraint. Obviously, with these views, researchers are expanding their inspection areas on asset structure.

Lately few literatures on this subject are emerging. Based on the above literatures and their findings, this article attempts to test asset structure change over 2006 through 2013, which is across the special period near 2008 , in order to find probable tendency of asset structure in a certain type of industry of the United States market and provide ideas on asset structure policy.

\section{Data}

Manufacturing industry is normally the most important indicator of an economy in an industrialized developed country. In this article, the "major group 35-Industrial and Commercial Machinery and Computer Equipment" of "Division D-manufacturing" in Standard Industrial Classification (SIC) is chosen as the object to investigate. It includes establishments engaged in manufacturing industrial and commercial machinery and equipment and computers. Using SIC or North American Industrial Classification System (NAICS) codes is a practical way to identify and compare firms in the main stock markets in the US. This article prefers SIC to NAICS or the Industry Classification Benchmark (ICB), which is accepted and used in NYSE, when the search of sample industry as SIC is still widely used under SEC, though NAICS has been adopted as the primary industry classification system since 1997.

In choosing sample firms, 157 firms among the above major group 35 with consecutive eight-year 10-K annual reports (fiscal year of 2006 to 2013, 1,256 observations) are screened out. The data used in this research is abstracted from Edgar, MSN, Yahoo, and Google, or calculated by the authors, except otherwise indicated.

$10-\mathrm{K}$ reports of those sample firms, though they may have been filed on different dates of a year, which result from different fiscal year of the listed companies, are always superior and preferable to other types of reports in the same year, since the former is generally audited by CPA and the latter are normally unaudited. If the fiscal year of a company ends in the early months of a calendar year, the fiscal year-end annual report should be treated as the report for the previous year, because most part of the report covers the operation year prior to the current calendar year (MFRI, DGTW, and CMCO as the examples). If, occasionally, there was no $10-\mathrm{K}$ of a year for the specific company, then its latest $10-\mathrm{Q}$ is selected for the substitution. Latest 10-K/A is preferable to $10-\mathrm{K}$. Some financial data are from $10-\mathrm{Q}$ for substitution, especially for those firms who terminated in 2013. 10-K of 2008 serves as a turning point when the trend is investigated. 
Changes in ownership operations in the market always happen from time to time to break the continuity of financial condition and asset structure data of acquired companies. These transactions also affect the process of choosing sample companies. Most of the initial chosen samples are filtered out once any acquirement transaction appeared. The time lag of different fiscal year among different companies is disregarded because of the continuous time series of financial statements. If a company changed its fiscal year, the $10-\mathrm{K}$ annual report of that right year may have not filed. Therefore, a 10-Q quarter report is chosen instead. If a firm has more than one class of stocks, "A-share" is preferable. Some data, which are obtained from nearly non-operating companies, or affected significantly by merger and acquisition (M\&A), have been expelled. All the authors have done for the data screening is to reinforce the qualification and representativeness of the sample companies.

\section{Methodology and Model}

\section{Panel Data}

To some extent, panel data models may allow for analysis to a number of important economic issues that cannot be addressed using cross-sectional or time-series data individually and are often superior to those data, because it combines both of the data information for the analysis. Due to the pattern of the chosen sample data, it employs panel Workfile in EVIEWS, which is more applicable to a micro-panel data set.

\section{Variables}

ROA is commonly used as net income/total asset (NI/TA) and a useful indicator for comparing peer companies in the same industry. It remains in the same industry, so it will stay to be the similar level and not vary widely. Some investors add interest expense back into net income when performing this calculation, because they would like to use operating returns before cost of borrowing. Then ROA $=$ NI/TA is got.

Asset structure ratio $\left(\mathrm{R}_{\mathrm{A}}\right)$ is equal to current assets divided by total assets. Current asset is closely related to working capital, though this paper does not take account of any current liability here, because it is concerned with the sole effect caused by current asset and its proportion. In addition, the part of current asset has been distinguished clearly from the rest of assets in the financial statement. It can be used as the proxy of asset structure and is a determining factor of firm liquidity.

ROE (net income/shareholder's equity) measures a firm's profitability on the side of shareholders and is widely used in most situations.

Furthermore, in order to avoid spurious regression, other two control variables are included in the regression process as followed: Debt ratio $\left(\mathrm{R}_{\mathrm{D}}\right)$ is calculated by debt/total asset $(\mathrm{TA})$ and $\log (\mathrm{TA})$ is equal to $\log$ (total asset).

\section{Generalized Moment Method-diff}

Arellano and Bond (1991) developed generalized moment method (GMM) based on first difference of the dependent variable, as:

$$
\begin{aligned}
& y_{i t}=\alpha y_{i t-1}+\alpha_{i}+\varepsilon_{i t},|\alpha|<1 \\
& i=1,2, \cdots, N, t=1,2, \cdots, T
\end{aligned}
$$

The advantages of GMM include that it may not lead to parameter heterogeneity in the model specification or avoid inconsistent results in simple dynamic panel models via introducing necessary instrumental variable 
estimators. Therefore, it is used in the following procedure for testing the relationship between ROA and the asset structure.

\section{Hypothesis and Model}

Authors are interested in whether ROA is correlated and how it is related to asset structure $\left(\mathrm{R}_{\mathrm{A}}\right)$. Therefore, authors build the following two hypotheses. If $\mathrm{H}_{1}$ holds after examination, then it can explain that $\mathrm{R}_{\mathrm{A}}$ is commonly viewed as a positive determinant of ROA.

$\mathrm{H}_{0}: \mathrm{R}_{\mathrm{A}}$ is not or negatively related to ROA.

$H_{1}: R_{A}$ is positively related to ROA.

The GMM model is

$$
R O A_{i t}=\alpha_{i} R O A_{i t-1}+\beta_{1 i} R_{A i t}+\beta_{2 i} R_{D i t}+\beta_{3 i} \log (T A)_{i t}+v_{i}+u_{i t}
$$

where $i=1,2, \cdots, N, t=1,2, \cdots, T$, the other notations have been specified above.

\section{Results and Analysis}

When authors review the individual ratio curve of current assets to total assets, they appear to cluster near 0.5 to 0.7 as showed in Figure 1. Among those curves, few seem to be volatile dramatically out of most of stable curves and other few are quite lower than normal trend.

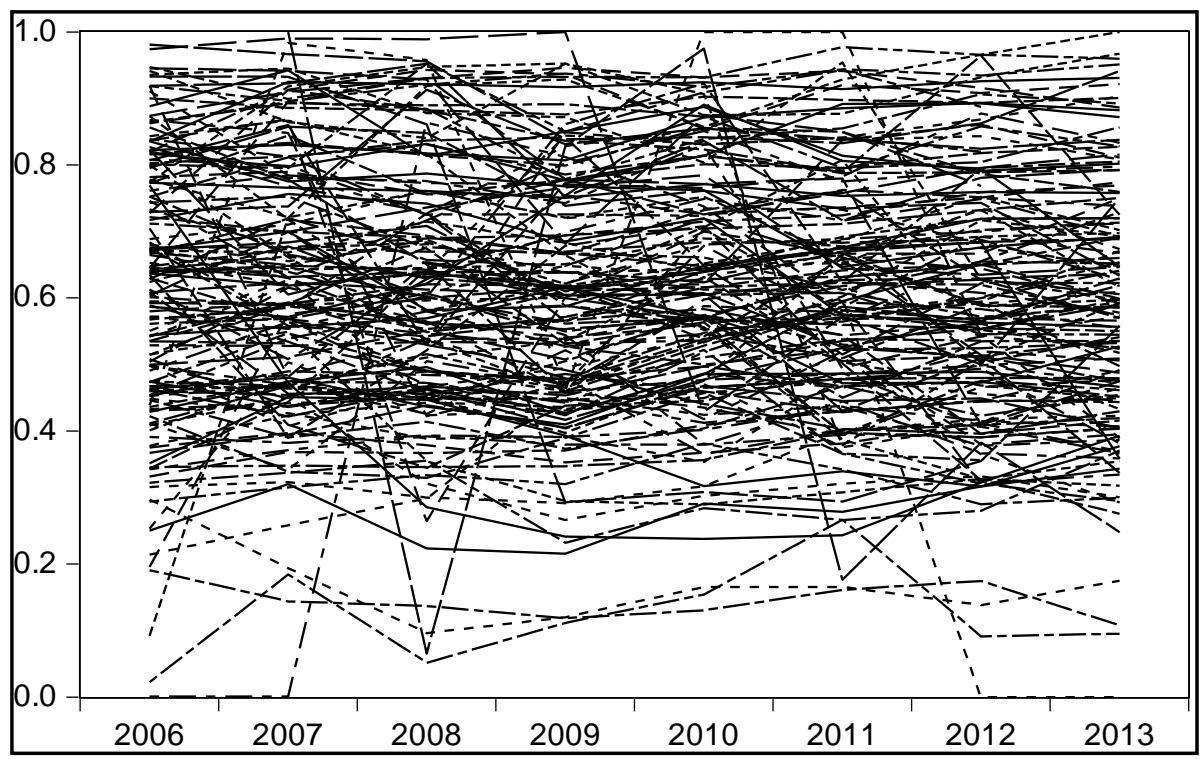

Figure 1. Current asset to total asset ratio of the 157 sample companies.

The test of sample mean shows that it equals to 0.603460 with a small standard deviation of 0.012695 . The whole sample presents an obvious stability of current asset ratio. The findings are presented in Table 1.

The extent of stability is further illustrated by the test of individual time series of current asset ratio. The summary test of group unit root, as in Table 2, shows the 157 sample series, 1,037 observations, rejects the null hypothesis of unit root process, and proves that the summary of the sample series is stable as described above. Based on this sense, along with the above tests, it can be asserted that the aggregate trend of the asset structure has not changed through the observation period under any test type of LLC, Im, Pesaran and Shin W-stat, ADF, or PP. 
Table 1

Test of Average Current Asset Ratio Mean

\begin{tabular}{lll}
\hline Hypothesis Testing for SER01_AVERAGEOFCA2TA & & \\
\hline Sample: 20062013 & & \\
Included observations: 8 & & \\
Test of hypothesis: Mean $=0.600000$ & Probability \\
Sample Mean $=0.603460$ & $\underline{\text { Value }}$ & 0.4660 \\
Sample Std. Dev. $=0.012695$ & 0.770820 & \\
Method &
\end{tabular}

Table 2

Test of Individual Time Series of Current Asset Ratio

Group unit root test: Summary

Sample: 20062013

Exogenous variables: Individual effects

Automatic selection of maximum lags

Automatic lag length selection based on SIC: 0 to 1

Newey-West automatic bandwidth selection and Bartlett kernel

\begin{tabular}{|c|c|c|c|c|}
\hline Method & Statistic & Prob. $* *$ & Cross-sections & Obs \\
\hline \multicolumn{5}{|c|}{ Null: Unit root (assumes common unit root process) } \\
\hline Levin, Lin, and Chu $t^{*}$ & -24.0362 & 0.0000 & 157 & 1,037 \\
\hline \multicolumn{5}{|c|}{ Null: Unit root (assumes individual unit root process) } \\
\hline Im, Pesaran and Shin W-stat & -4.02225 & 0.0000 & 157 & 1,037 \\
\hline ADF_-Fisher Chi-square & 460.175 & 0.0000 & 157 & 1,037 \\
\hline $\mathrm{PP}$-Fisher Chi-square & 408.316 & 0.0003 & 157 & 1,092 \\
\hline
\end{tabular}

Notes. ** Probabilities for Fisher tests are computed using an asymptotic Chi-square distribution; all other tests assume asymptotic normality.

The statement given above does not mean the same trend in other situations. When authors investigate some individual sample series or even the average value of the current asset ratio, things may be different. Apparently, Figure 2 shows a slight downward curve of the average current asset ratio. Immediately, this change indicates that the liquidity and solvency may have slightly decreased in average, and that may result in increasing operating leverage, operating risk, and future return on asset. This is may result from firm liquidity constraint during those period. Relating current asset to current liability, the current ratio measures the solvency more precisely. Authors can see the slight increase of average current ratio over the same period in Figure 3 and the discrepancy of the two curves in Figure 4. That is equal to say, averagely, the management pays more attention to the financial risk when it decreases the current asset ratio, which is a better move in the longer run.

Test results showed in Table 3 demonstrate the expected outcomes. All the variables, $R O A(-1), R_{A}$, and ROE are positively related to ROA, which are represented by the sign ahead of these variables. Moreover, the result is significant under the criteria because of the very small probability of $0.0000,0.0005$, and 0.0000 . Authors are quite straightforward and certain to reject $\mathrm{H}_{0}$ and accept $\mathrm{H}_{1}$, that is, $\mathrm{R}_{\mathrm{A}}$ is positively related to ROA significantly. 


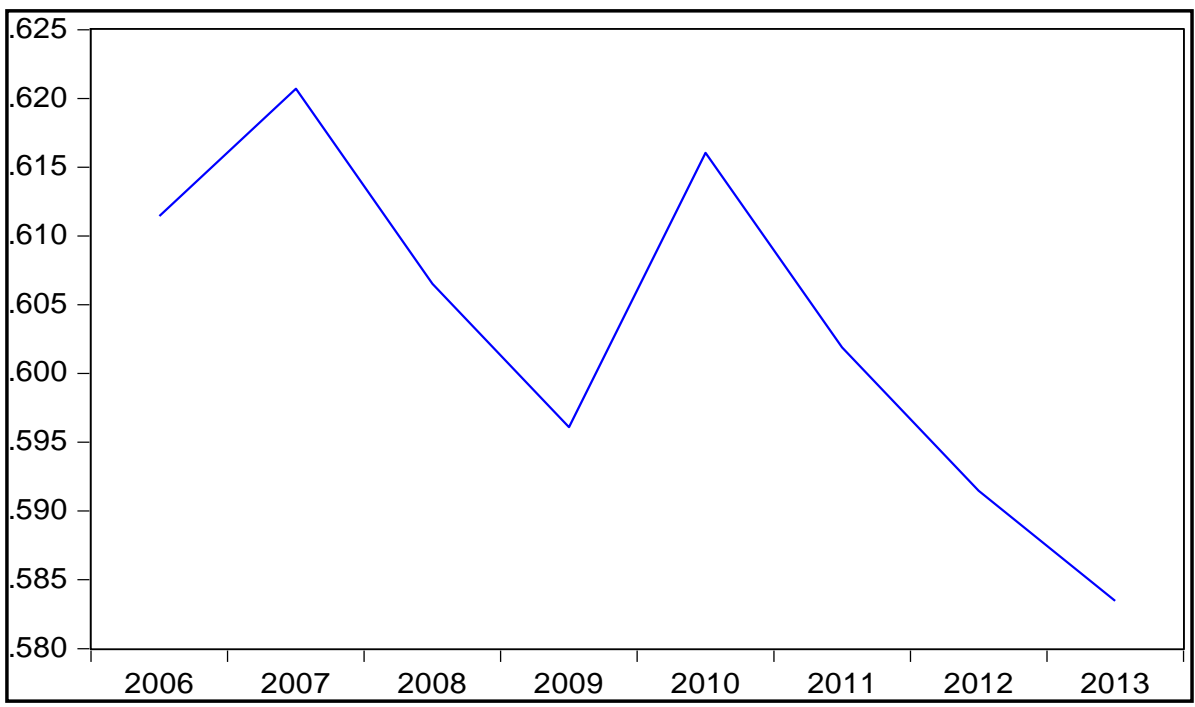

Figure 2. The average of current asset to total asset ratio through 2006 to 2013.

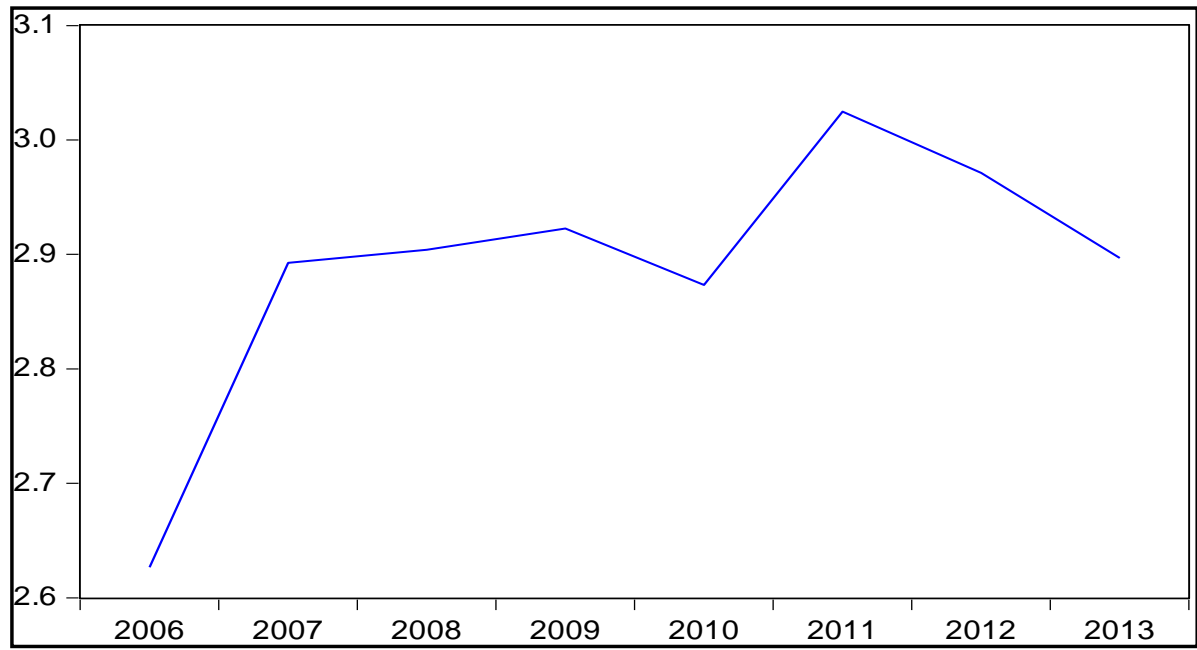

Figure 3. The average of current ratio through 2006 to 2013.

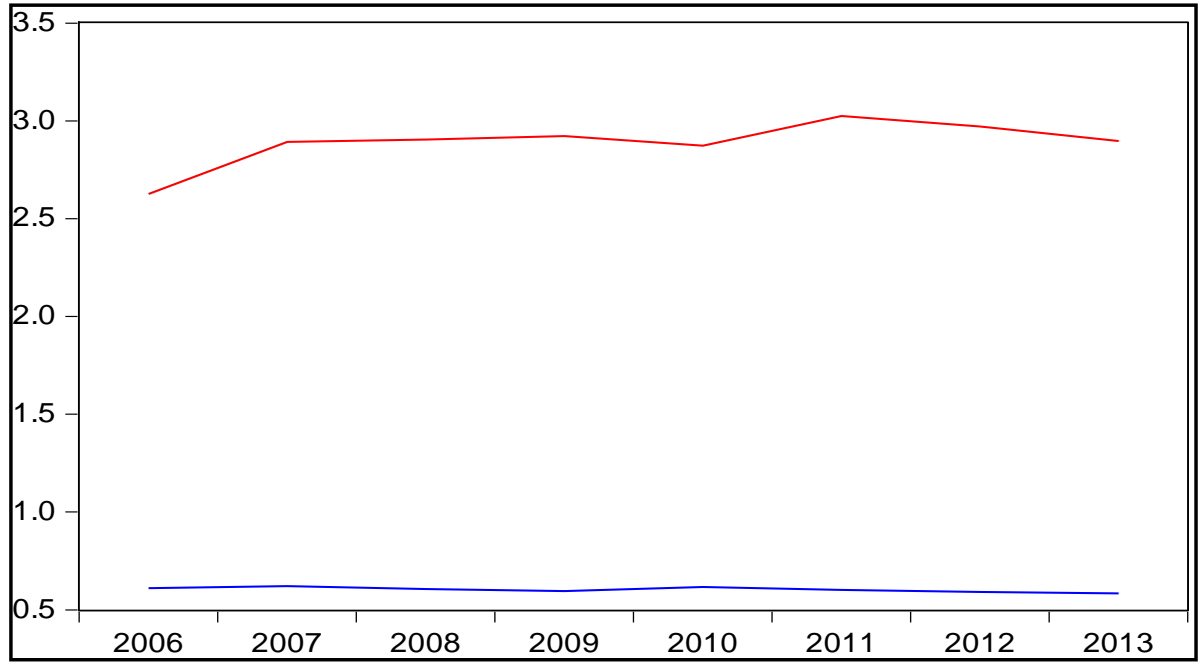

Figure 4. The discrepancy of current asset ratio and current ratio. 
Table 3

Test of ROA Model

Dependent variable: ROA

Method: Panel generalized method of moments

Transformation: First Differences

Sample (adjusted): 20082013

Periods included: 6

Cross-sections included: 137

Total panel (unbalanced) observations: 798

White period instrument weighting matrix

White period standard errors and covariance (d.f. corrected)

Instrument specification: @DYN (ROA,-2)

Constant added to instrument list

\begin{tabular}{|c|c|c|c|c|}
\hline Variable & Coefficient & Std. Error & $t$-Statistic & Prob. \\
\hline $\operatorname{ROA}(-1)$ & 0.324785 & 0.021115 & 15.38153 & 0.0000 \\
\hline $\mathrm{R}_{\mathrm{A}}$ & 42.70295 & 12.27969 & 3.477527 & 0.0005 \\
\hline ROE & 0.197362 & 0.013911 & 14.18793 & 0.0000 \\
\hline $\mathrm{R}_{\mathrm{D}}$ & 0.063835 & 0.357242 & 0.178689 & 0.8582 \\
\hline $\log (\mathrm{TA})$ & -0.000233 & 0.000505 & -0.461171 & 0.6448 \\
\hline \multicolumn{5}{|c|}{ Effects specification } \\
\hline \multicolumn{5}{|c|}{ Cross-section fixed (first differences) } \\
\hline Mean dependent var & 0.401128 & S.D. dependent var & & 21.96733 \\
\hline S.E. of regression & 27.08573 & Sum squared resid & & $581,774.1$ \\
\hline$J$-statistic & 15.42473 & Instrument rank & & 21 \\
\hline
\end{tabular}

\section{Conclusions}

This paper investigates the asset structure of chosen listed companies in U.S. and its change trend and develops several empirical models to conclude on the ground of analysis. It is found, as expected but differs from previous literature works, that the average of the asset structure almost remains the same level through the period of 2006 to 2013, but at the later part of the period, the current asset ratio goes slightly downward. When comparing to the current ratio in the same period, the curve presents a discrepant trend of slight upward. Overall, that discrepancy shows a kind of conservatism in asset management and financial risk.

The data set used indicates that most of the sample companies keep their normal asset structure near to 0.6 and remain constant, while few of them deviate from that normal level and are volatile remarkably. The figure 0.6 seems to be the most favorable ratio of current asset to total asset, though some exceptional data still exist. This number is believed to be at the discretion of the firm management and viewed as a reasonable level of current asset. Therefore, this level might be useful for the decision-making in asset management.

The findings support the hypothesis that managerial decision on asset structure has a strong effect on firm return on asset. The ratio of current asset to total asset is one of the most important determinants of ROA. The effect is straightforward and significant. These findings may be very useful for strengthening the concept of asset structure and for the financial management, especially for the managers who are seeking better practice of financial policy for asset investment and liquidity of asset. When these findings are used as a norm or benchmark, those firms who stay in the same industry are able to adjust their asset structure according to their asset investment strategy. 


\section{References}

Akintoye, I. (2008). Effect of capital structure on firms' performance: The Nigerian experience. European Journal of Economics, Finance and Administrative Sciences, 10, 233-243.

Ambrose, B. W., \& Megginson, W. L. (1992). The role of asset structure, ownership structure, and takeover defenses in determining acquisition likelihood. Journal of Financial \& Quantitative Analysis, 27(4), 575-589.

An, Z. (2013). Private property rights, investment patterns, and asset structure. Economics \& Politics, 25(3), 481-495.

Arbidane, I., \& Zelgalve, E. (2012). Current assets structure and exploration of business in Latvia. European Integration Studies, 6, 185-191.

Arellano, M., \& Bond, S. (1991). Some tests of specification for panel data: Monte Carlo evidence and an application to employment equations. The Review of Economic Studies, 58(2), 277-297.

Constand, R. L., Osteryoung, J. S., \& Nast, D. A. (1991). Asset-based financing and the determinants of capital structure in the small firm. Advances in Small Business Finance, 21, 29-45.

Czyzewski, A. B., \& Hicks, D. W. (1992). Hold onto your cash. Management Accounting, 73(3), 4-4.

De Almeida, J. R., \& Eid, W. (2014). Access to finance, working capital management and company value: Evidences from Brazilian companies listed on BM\&FBOVESPA. Journal of Business Research, 67(5), 924-934.

Ding, S., Guariglia, A., \& Knight, J. (2013). Investment and financing constraints in China: Does working capital management make a difference? Journal of Banking \& Finance, 37(5), 1490-1507.

Jose, M. L., Lancaster, C., \& Stevens, J. L. (1996). Corporate returns and cash conversion cycles. Journal of Economics \& Finance, 20(1), 33.

Modigliani, F., \& Miller, M. H. (1958). The cost of capital, corporation finance and the theory of investment. American Economic Review, 48(3), 261.

Muritala, T. A., \& Ajibola, O. B. (2013). Does capital structure enhance firm performance? Evidence from Nigeria. The IUP Journal of Accounting Research \& Audit Practices, 12(4), 43-55.

Myers, S. C. (1977). Determinants of corporate borrowing. Journal of Financial Economics, 5(2), 147-175.

Myers, S. C. (1984). The capital structure puzzle. Journal of Finance, 39(3), 575-592.

Myers, S. C., \& Majluf, N. S. (1984). Corporate financing and investment decisions when firms have information that investors do not have. Journal of Financial Economics, 13(2), 187-221.

Sanyal, P., \& Mann, C. L. (2010). The financial structure of startup firms: The role of assets, information, and entrepreneur characteristics. Boston: Federal Reserve Bank of Boston.

Sibilkov, V. (2009). Asset liquidity and capital structure. Journal of Financial and Quantitative Analysis, 44(5), $1173-1173$.

Stulz, R. M., \& Johnson, H. (1985). An analysis of secured debt. Journal of Financial Economics, 14(4), 501-521. 